\title{
Comparative Anatomy of the Cardiac Septomarginal Trabecula (Moderator Band)
}

\author{
Heshmat SW Haroun* \\ Professor of Anatomy and Embryology, Cairo University, Egypt
}

Submission: April 19, 2017; Published: May 06, 2017

*Corresponding author: Heshmat SW Haroun, Professor of Anatomy and Embryology, Faculty of Medicine, Cairo University, Egypt, Email: heshmatsabet@gmail.com

\begin{abstract}
The septomarginal trabecula (SMT) is a constant component of human heart. In man, it connects the interventricular septum with the anterior wall of the right ventricle at the base of the anterior papillary muscle. It is also present in non-human mammals where it stretches between the bases of the muscles papilaris subarteriosus and magnus. Its morphology and structure varies in different species. It carries the continuation of the right bundle branch of the conducting system of the heart. It is constituted of ordinary cardiac myocytes around and in between the Purkinje myocytes. In addition, it conveys one of the large interventricular septal arteries.
\end{abstract}

Keywords: Septomarginal trabecula; Moderator band; Morphology; Structure; Functions; Comparative

\section{Introduction}

Comparative researches have been extensively conducted on the components of the right ventricle of the heart in man and other primates. The results of these studies are assumed to be fundamental from both academic and therapeutic points of view. Proper selection of an appropriate animal heart tissue could be of great value for cardiac bioprosthesis in man [1-6].

The septomarginal trabecula (trabecula septomarginalis or moderator band) is present in all human hearts and also in the hearts of other primates. It forms the lower limit of the trabecular inflow tract of the right ventricle. It bridges between the lower part of the interventricular septum and the base of the anterior papillary muscle; although it sometimes exhibits some variations of extension. It also conveys the continuation of the right bundle branch of the specialized conducting system of the heart [7-9].

\section{Morphological and Structural Aspects of the Septomarginal Trabecula}

In human hearts, the septomarginal trabecula (SMT) is described as a shining small, thin and flattened band that is frequently duplicated particularly near its ends. It extends from the septal wall of the right ventricle at the base of one of the masses of the septal papillary muscle to the sternocostal wall of the right ventricle at the base of the anterior papillary muscle; being smaller in females. Microscopic examination of the human SMT has displayed a mass of ordinary myocardial fibers surrounding a less-stained fibrocellular tissue column which consists of few conducting cells, many collagenous and few elastic fibers. The specialized conducting cells are larger than the surrounding ordinary cardiac myocytes, marginally multinucleated, aligned edge to edge in parallel clusters, and increasing in size as the SMT approaches the base of the anterior papillary muscle [10]. In chagasic patients with right bundle branch lesion, the SMT has demonstrated variable degrees of mononuclear cell infiltrate and fibrosis [11].

In a study dissecting the muscle bundles constituting the SMT, in cadaveric human adult hearts of both sexes, eight morphological types could be observed based on the origin, course, and termination of these constituting bundles. The trabecula was composed of two components: septal and septal- papillary. The septal component was either visible macroscopically or only on dissection while the septal-papillary one was constantly visible and fleshy. At its junction with the anterior papillary muscle, the trabecula was either single or presenting ramifications [12]. In another study, on following the course of the SMT in the lumen of the human right ventricle and its relation to the anterior papillary muscle, four morphological types (I-IV) were distinguished. The most common was type III 
where the trabecula was undivided and firmly connecting to the anterior papillary muscle [13].

The supraventricular crest (crista supraventricularis) is a fleshy trabecula of the right ventricle that serves in directing the blood flow [14]. This crest, together with the SMT, forms a morphological unity that is commonly found in the right ventricle. In preserved human hearts, it was found that the division of the lower part of the crista supraventricularis and the development of the SMT had led to the emergence of five morphological types (A, B, C, D \& E). The most common was type B that contained two muscular bundles [15]. In goat hearts, the right SMT was constantly present and it measured $1.3-2.6 \mathrm{~cm}$ in length. It could have a septal component originating from the rostral part of the interventricular septum, going to the ventricular wall or to the middle or caudal third of the muscle papillaris magnus (69\%). It might lack a septal component where it was solely attached to this muscle (31\%) [16].

In porcine hearts, the SMT has been demonstrated to extend from the interventricular septum to the free wall of the right ventricular cavity. It measures $2.9 \pm 0.6 \mathrm{~mm}$ in diameter. On cross-section of the trabecula, clumps of conductive Purkinje fibers are located at its periphery and in the center around the blood vessels. Large amounts of myocardial fibers surround the conductive elements [17]. The porcine SMT exhibits anatomical features different from those of the human trabecula. In pigs, the muscle bundle of the SMT and the right bundle branch of the conducting complex are dissociated. The right bundle branch is a narrow band that extends from the upper part of the interventricular septum to the upper part of the anterior papillary muscle. The muscle bundle of the trabecula is a resistant crest that stretches between the lower parts of the same septum and muscle [18]. Electron microscopy of porcine hearts has revealed that the myofibrils in Purkinje fibers (P-fibers) from the septal walls have a cart-wheel arrangement, whereas those in P-fibers of the SMT show a parallel alignment. This difference in myofibrillar arrangements of the P-fibers in these two locations are considered as a structural adaptation to the mechanical stress exerted during systolic-diastolic activity [19].

In dog hearts, age-related structural changes in the right SMT are reported. The connective tissue of the trabeculae of younger dogs has fewer elastic fibers than that of older dogs. In addition, the trabeculae of older dogs exhibit scattered foci of extracellular fat droplets, and their junctional regions with the ventricular wall are frequently heavily laden with fat. The Purkinje cells of younger dogs are mainly cuboidal with few and poorly developed myofibrils whilst in older dogs they resemble functional myocytes with well developed and longitudinally arranged myofibrils [20].

In other non-human mammals like camel, sheep and monkey, the SMT is described as a glistening band extending from the interventricular septum just distal to the muscle papillaris subarteriosus to the ventrolateral wall of the right ventricle at the base of the muscle papillaris magnus. In camel, it is thick, mostly rounded and always kinked unless the ventricular walls are stretched. Compared to human SMT, the faintly stained fibrocellular tract in the center of the camel SMT is thicker and more linear with its cells more tightly closer to each other. In sheep, the SMT appears moderately thick, mostly rounded with flattened ends, and kinked; it has characteristic mosaic-like foamy cells along its core. In monkey, the SMT is short, straight, flattened and moderately broad with poorly developed content $\mathrm{f}$ cells and connective tissue [10] (Figure 1).

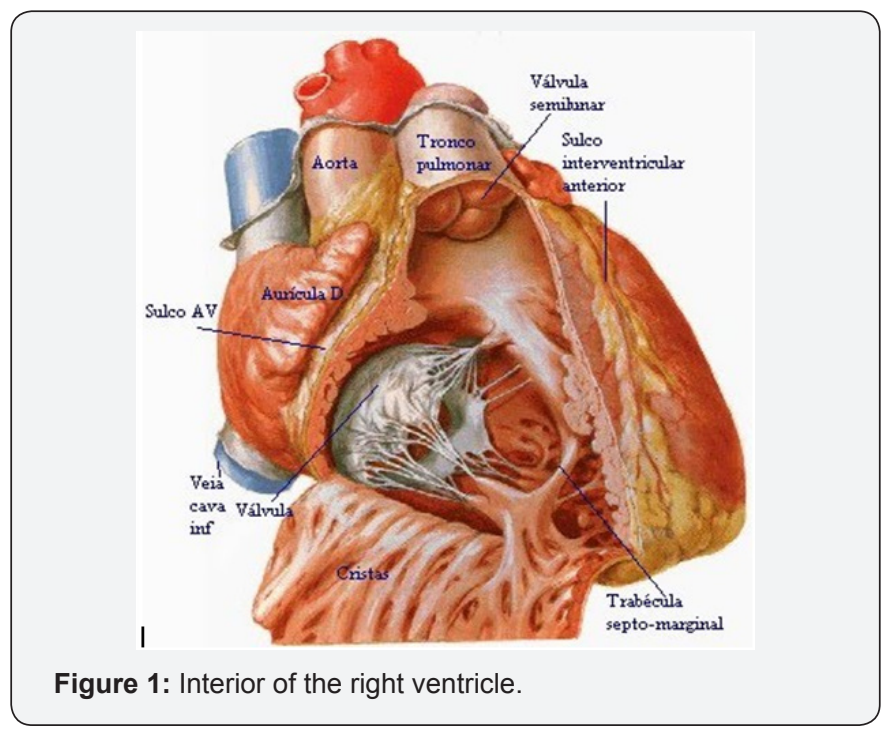

\section{Functional Aspects of the Septomarginal Trabecula}

The SMT carries the continuation of the right bundle branch of the conducting system of the heart. It was early thought to prevent over distension of the right ventricle; hence its old name "the moderator band" [21]. The position of a large interventricular septal artery could be predicted from coronary angiography and from the morphology of the anterior extension of the SMT [22]. In postmortem studies, one large septal artery has been dissected in the lower border of the anterior limb of the SMT. When more than one large septal artery exist, the first is located within the subendocardial outflow tract of the left ventricle, the second in the lower border of the anterior limb of the SMT, and the third at about $1.5 \mathrm{~cm}$ below the second. Knowledge of position of the septal arteries can increase the safety of operations performed on the outflow of the interventricular septum in aortic valve disease and Fallot's tetralogy [23].

\section{Conclusion}

The SMT, in man and other mammals, has been always observed to contain a long artery originating from the left coronary artery to the anterior papillary muscle; it joins some branches of the right coronary artery. A few various venous capillaries are also seen going to the anterior interventricular vein or directly mouthing into the cavity of the right ventricle [24]. 


\section{References}

1. Nozynski JK, Zembala-Nozynska E, Wilczek P, Wszolek J (2003) Integrative measurements of calcification in stented, antibiotic sterilized and cryopreserved sheep biological valves implanted for one year in tricuspid position. Ann Transplant 8(1): 45-54.

2. Haroun HSW, Al-Sherif Al-MB, Doss SHE (1999) A comparative anatomical and morphometric study of tricuspid valve in man and pig. Egypt J Anat 22(2): 249-284.

3. Hayashi J, Saito A, Yamamoto K, Watanabe H, Ohzeki H, et al. (1996) Is a bioprosthesis preferable in tricuspid valve replacement? J Thorac Cardiovasc Surg 44(5): 230-233.

4. Munro AI, Jamieson WR, Tyers GF, Germann E (1995) Tricuspid valve replacement: porcine bioprosthesis and mechanical bioprosthesis. Ann Thorac Surg 60 (2 Suppl): S470-473.

5. Icardo JM, Arrechedera H, Colvee E (1993) The atrioventricular valves of the mouse. I- A scanning electron microscopic study. J Anat 182 (1) 87-94.

6. Harasaki H, Suzuki I, Tanaka J, Hanano H, Torisu M (1975) Ultrastructure research of the endocardial endothelium of monkeys. Arch Histol Jpn 38 (1): 71-84.

7. Kosiński A, Zajączkowski M, Kuta W, Kozłowski D, Szpinda M, et al (2013) Septomarginal trabecula and anterior papillary muscle in primate hearts: developmental issues. Folia Morphol (Warsz) 72(3) 202-209.

8. Williams PL, Bannister LH, Berry MM, Collins P, Dyson M, et al. (1995) Gray's Anatomy (38 th edn.), Churchill Livingstone, New York, Edinburgh, London, Tokyo and Melbourne, UK, p. 1480.

9. Sinnatamby CS (1999) Last's Anatomy: Regional and Applied (10 ${ }^{\text {th }}$ edn.), Churchill Livingstone, Edinburgh, London, New York, Philadelphia, Sydney, Toronto, UK, p. 194.

10. Heshmat SW Haroun, Mohamed A Al-Motabagani (2005) The cardiac septomarginal trabecula in man and some mammals. J Experim Clin Anat (JECA) 4(2): 1-9.

11. Rocha A, Lima Filho JL, Silva Z, Heredia RA, Lopes ER (1994) The histopathology of the trabecular section of the right branch of the bundle of His in chronic chagasic patients with a right bundle-branch block. Arq Bras Cardiol 63(2): 97-100.

12. Bandeira ST, Wafae GC, Ruiz C, Nascimento SR, Fernandes JR, et al. (2011) Morphological classification of the septomarginal trabecula in humans. Folia Morphol (Warsz) 70(4): 300-304.
13. Kosiński A, Kozłowski D, Nowiński J, Lewicka E, Dąbrowska-Kugacka A, et al. (2010) Morphogenetic aspects of the septomarginal trabecula in the human heart. Arch Med Sci 6(5): 733-743.

14. Wafae N, Menegucci D, Wafae GC, Ruiz CR (2010) Anatomy of the supraventricular crest in human hearts. Folia Morphol (Warsz) 69(1): 42-46.

15. Kosiński A, Nowiński J, Kozłowski D, Piwko G, Kuta W, et al. (2007) The crista supraventricularis in the human heart and its role in the morphogenesis of the septomarginal trabecula. Ann Anat 189(5): 447456 .

16. Leão CR, Pacha DL, Cyriaco T, da Silva C, Wafae N, et al. (2010) Anatomy of the septomarginal trabecula in goat hearts. Ital J Anat Embryol 115(3): 229-234

17. Gulyaeva AS, Roshchevskaya IM (2012) Morphology of moderator bands (septomarginal trabecula) in porcine heart ventricles. Anat Histol Embryol 41(5): 326-332.

18. Rocha H, Eliziário LF, Wafae GC, Silva NC, Ruiz CR, et al. (2010) Anatomy of the septomarginal trabecula in Landrace pig hearts. Morphologie 94(305): 26-29.

19. Bytzer P (1979) Scanning electron microscopy of Purkinje fibers of the pig heart. Anat Anz 145(4): 390-403.

20. Armiger IC, Urthaler F, James TN (1979) Morphological changes in the right ventricular septomarginal trabecula (false-tendon) during maturation and ageing in the dog heart. J Anat 129(4): 805-817.

21. Sisson S, Grossman JD (1975) Getty's Anatomy of Domestic Animals ( $5^{\text {th }}$ edn.), W.B. Saunders Company, Philadelphia, Toronto, London, UK, 1: $166-168$

22. Melo JQ, Abecassis M, Neves J, Calquinha J, Ramos S, et al. (1995) Can the location of the large septal artery be predicted? Eur J Cardiothorac Surg 9(11): 628-630.

23. Melo JQ, Abecasis ME, Neves JS, Bruges LO, Ramos SB, et al. (1995) The large septal arteries in normal hearts, in aortic valve disease, and in tetralogy of Fallot. Ann Thorac Surg 60(6): S626-628.

24. Depreux R, Mestdagh H, Houcke M (1975) Comparative anatomy of the arterial and venous vascularization of the septomarginal trabecula in man and mammals. Bull Assoc Anat (Nancy) 59(167): 847-854.

\section{Your next submission with Juniper Publishers will reach you the below assets}

- Quality Editorial service

- Swift Peer Review

- Reprints availability

- E-prints Service

- Manuscript Podcast for convenient understanding

- Global attainment for your research

- Manuscript accessibility in different formats

( Pdf, E-pub, Full Text, Audio)

- Unceasing customer service

Track the below URL for one-step submission https://juniperpublishers.com/online-submission.php 